\title{
Identifikasi Unsur Pembentuk Karakter Langgam Arsitektur Klasik Pada Gereja Katolik Kelahiran Santa Perawan Maria
}

\author{
Krisnina Dohan Limantara ${ }^{1}$, Josephine Roosandriantini ${ }^{1 *}$ \\ ${ }^{1}$ Program Studi Arsitektur, Fakultas Teknik, Universitas Katolik Darma Cendika \\ *Penulis Korespondensi: jose.roo@ukdc.ac.id
}

\begin{abstract}
Abstrak:
Gereja Kelahiran Santa Perawan Maria merupakan salah satu gereja tua di Indonesia yang terletak di Jalan Kepanjen Surabaya. Gereja ini memiliki nilai sejarah dan langgam arsitektur klasik yang tampak pada façade bangunan. Penelitian ini bertujuan untuk mengidentifikasi unsur pembentuk karakter langgam arsitektur Klasik pada Gereja Katolik Kelahiran Santa Perawan Maria dengan memperlihatkan elemen-elemen arsitektural yang membentuk karakter langgam arsitektur klasik. Identifikasi yang dilakukan terhadap Gereja Katolik Kelahiran Santa Perawan Maria ini dapat menambah wawasan dan pengetahuan mengenai langgam arsitektur klasik dan mengkategorikan gereja tersebut sebagai bangunan kuno atau cagar budaya. Identifikasi yang dilakukan merupakan sebuah hasil analisa yaitu tabel untuk memperlihatkan detail lima rupa yaitu perdindingan, perlindungan, perlubangan, pertiangan, dan persolekan dari Gereja Kelahiran Santa Perawan Maria. Selain itu juga mengidentifikasi unsur karakter langgam arsitektur klasik yang ada pada tiap elemen arsitektual. Metode penelitian deskriptif analisis yang digunakan yaitu metode pengumpulan data, pengolahan data, serta penarikan kesimpulan dari analisa tabel identifikasi langgam arsitektur klasik. Metode pengumpulan data yang dilakukan dengan studi literatur, survei, yang meliputi pengamatan, dan pendokumentasian secara langsung berupa foto Gereja Kelahiran Santa Perawan Maria. Analisa selain tabel juga berbentuk prosentase langgam yang diterapkan pada gereja tersebut. Hasil penelitian menunjukkan bahwa bangunan Gereja Katolik Kelahiran Santa Perawan Maria signifikan lebih menerapkan langgam arsitektur klasik. Variabel yang terlihat lebih dominan menerapkan langgam arsitektur klasik, yaitu pada ornament, bentuk jendela, façade bangunan, dan interior.
\end{abstract}

Kata Kunci: Arsitektur; Gereja; Identifikasi; Klasik; Langgam

\section{Latar Belakang}

Arsitektur merupakan produk hasil pemikiran manusia yang menggambarkan hubungan dirinya dengan konteks sosial maupun setting lingkungan sekitar (Wihardyanto \& Sudaryono, 2020), tetapi juga merupakan wadah untuk berekspresi secara kebudayaan untuk menata kehidupan secara jasmani, psikologis, dan sosial. Arsitektur menjadi suatu bagian dari peradaban manusia yang berhubungan dalam berbagai aspek kehidupan, yaitu: seni, teknik, ruang, letak/geografi dan sejarah. Jika dilihat dari bidang seni, arsitektur merupakan seni pada bangunan, seperti yang tampak pada bentuk dan ornamennya. Sedangkan, dalam aspek teknik, arsitektur dapat diterjemahkan sebagai metode dalam mendirikan suatu bangunan, hal tersebut terwujud baik dalam proses perancangan, konstruksi dan struktur, maupun nilai keindahannya. Kemudian, dari segi ruang, arsitektur merupakan usaha dalam memenuhi kebutuhan ruang manusia untuk melakukan berbagai kegiatan.

Bangunan bersejarah yang merupakan warisan atau peninggalan sejak Indonesia masih jajahan Belanda, sampai saat pada zaman modern ini, pembangunan yang terjadi terkadang dapat membawa dampak pada kelestarian obyek bersejarah (Tamimi et al., 2020). Adanya perkembangan sejarah arsitektur dapat memperlihatkan peranan yang sangat penting dalam mengidentifikasi sebuah obyek yang berkaitan dengan langgan atau bentukan arsitekturnya (Sukawi, 2004). Arsitektur selalu berkembang dan mengalami kemajuan di seni bangunan maupun ilmu struktur, seni bangunan kemudian mengakibatkan bermunculan ciri khas tiap langgam arsitektur seperti prinsip, konsep dan ciri identik sebuah langgam. Teori arsitektur klasik mulai dari Yunani berlanjut hingga zaman Gothic, yang banyak memunculkan keindahan visual yaitu menghadirkan cahaya yang datang, bentuk-bentuk jendela mawar, peningkatan sensasi persepsional hingga tingkat immaterial.

Indonesia mengalami perkembangan pada arsitektur Indonesia, terutama arsitektur gereja katolik mengalami perkembangan dalam bentuk fisiknya yaitu terkait fungsi, bentuk dan makna (Laurens, 2013). Arsitektur Gotik memiliki keunikan bentuk fisik yaitu dengan bentuk pointed arch (meruncing) yang dinyatakan sebagai simbol 
kesakralan, karena itu Gereja katolik menjadi bagian dari estetika arsitektur Gotik. Dunia arsitektur akan selalu memperoleh perubahan seiring dengan peralihan kualitas kebudayaan manusia. Perkembangan pembangunan yang terjadi hingga saat ini dapat dijadikan sebagai indikator kesuksesan dalam suatu bangsa dibidang pembangunan dari periode ke periode. Hasil dari pembangunan dapat dijadikan sebagai parameter, seberapa tinggi tingkat kultur yang ada pada masa tersebut (Saputra \& Prabowo, 2014). Seiring perkembangannya, arsitektur selalu memperoleh dampak dari berbagai langgam atau gaya yang berkembang pada zaman tertentu, sehingga akan mengalami beberapa periode perubahan. Bangunan Gereja Katolik yang memiliki wujud fisik adopsi dari langgam arsitektur klasik denahnya rata-rata memiliki bentuk salib, simetris dengan nave atau ruang umat di tengah. Terdapat choir di balkon belakang, dan juga ruang peralihan (setelah masuk pintu utama pengunjung) (Yunani, 2018).

Bangunan-bangunan yang telah lama berdiri bisa menjadi "saksi bisu" dari berbagai peristiwa maupun kejadian dimasa lampau. Oleh karena itu, selain memiliki nilai arsitektural yang berupa teknologi, konstruksi, ruang, keindahan, dan sebagainya, bangunan kuno juga mempunyai nilai sejarah yang tinggi (Sahmura \& Wahyuningrum, 2018). Seperti yang dikatakan oleh Antariksa (2017) bahwa suatu karya arsitektur dapat terlihat kualitasnya yaitu dari elemen dasar pembentuk arti, makna yang terlihat dari warna, bentuk, garis, dan tekstur (Agusintadewi et al., 2019). Elemen-elemen bangunan tersebut dapat terlihat pada fasade bangunan, sehingga tampilan keseluruhan bagian depan bangunan dapat menggambarkan karakter arsitekturalnya. Suatu bangunan dapat bertahan dalam waktu yang lama, maka bangunan tersebut dapat dijadikan sebagai bukti penegasan alangkah besarnya nilai sejarah dan kebudayaan yang tersembunyi di dalamnya. Hingga saat ini telah banyak bangunan yang memiliki nilai arsitektur maupun budaya serta sejarah yang tinggi yang dihancurkan ataupun dimusnahkan dengan alasan-alasan yang tidak sebanding dengan harga dari kehilangan bangunan tersebut. Rendahnya tingkat apresiasi yang diberikan terhadap kedua nilai tadi menjadi pemicu munculnya berbagai pertimbangan untuk memusnahkan bangunan bersejarah (Kumurur, 2015). Hal itu pastinya memberi dampak buruk yang akan merugikan di masa mendatang, baik itu pada diri sendiri maupun generasi penerus bangsa, karena mereka akan kehilangan bukti sejarah yang berharga. Oleh sebab itu, sudah sepatutnya kita untuk melindungi warisan sejarah yang saat ini masih ada.

Gereja Katolik Kelahiran Santa Perawan Maria adalah salah satu gereja tua di Surabaya, yang terletak di sebelah Gedung SMAK Frateran. Keberadaan Gereja ini adalah sebelum kemerdekaan Indonesia yaitu sekitar tahun 1899 dan di desain oleh arsitek yang Bernama W. Westmaas yang berasal dari Semarang. Gereja ini lebih dikenal dengan nama Gereja Kepanjen, mengalami perkembangan saat dikelola oleh Pastor Congregatio Misionaris. Pada tahun 1949 - 1950 gereja kepanjen ini mengalami kehancuran dan direnovasi ulang dengan melakukan beberapa perubahan dan pengembangan, yaitu tidak menggunakan menara, menambahkan ruang sakristi (untuk menyimpan benda suci dan tempat para pastor sebelum ibadah mulai), dan menambahkan ruang pengakuan dosa yang berada di sebelah kanan dan kiri. Pada tahun 1996, renovasi ketiga melakukan penambahan menara di sisi kanan dan kiri pintu masuk utama gereja. Beberapa renovasi yang dilakukan oleh Gereja Katolik Kelahiran Santa Perawan Maria (Kepanjen) ini yang masih mempertahankan bentuk asli bangunan, merupakan usaha pelestarian yang berguna untuk menjaga keaslian gereja itu. Bentuk asli Gereja ini merupakan warisan arsitektur klasik yang masih terjaga, sehingga obyek ini dipilih menjadi obyek penelitian ini agar dapat memperlihatkan unsur karakter arsitektur klasik yang diadopsi oleh Gereja Kepanjen ini.

Terdapat berbagai upaya yang dapat dilakukan untuk melindungi warisan sejarah yang berharga ini, salah satunya dengan mengenal langgam arsitektur pada suatu bangunan. Penelitian ini bertujuan untuk mengidentifikasi unsur pembentuk karakter arsitektur bangunan Gereja Katolik Kelahiran Santa Perawan Maria dengan mengacu pada penerapan arsitektur klasik pada unsur bangunan Gereja tersebut. Identifikasi unsur karakter arsitektur klasik pada Gereja Katolik Kelahiran Santa Perawan Maria, dilakukan dengan melihat detail elemen-elemen arsitektural yang mengadopsi dari arsitektur klasik, hal ini berguna untuk menambah wawasan dan pengetahuan mengenai langgam arsitektur klasik dan mengkategorikan gereja tersebut sebagai bangunan kuno atau cagar budaya.

\section{Metode}

Metode penelitian yang dipakai dalam penelitian ini adalah metode deskriptif analisis. Metode deskriptif analisis yaitu sebuah metode penelitian yang digunakan untuk terkait dengan obyek penelitian yang merupakan hasil dari pengamatan di lapangan. Hasil pengamatan atau survei tersebut digunakan untuk melihat adopsi langgam pada elemen-elemen pembentuk unsur karakter bangunan dari langgam bangunan, atap, interior, eksterior dan elemen arsitektural (Putra et al., 2017). Penelitian menggunakan metode kualitatif adalah penelitian yang hasil akhirnya berupa sebuah penjabaran yang memiliki tujuan untuk mendeskripsikan sebuah topik yang telah diteliti dengan maksud untuk memperoleh data dan informasi secara deskriptif yang tersaji dalam kata-kata tertulis secara konkret, dan tepat serta ilmiah (Saputra \& Prabowo, 2014).

\subsection{Metode Pengumpulan Data}

Pengumpulan data dari objek di lapangan dilakukan dengan cara sebagai berikut: 
a. Observasi (pengamatan secara langsung Gereja Katolik Kelahiran Santa Perawan Maria) yang meliputi elemen arsitektural mulai dari eksterior dan interior obyek.

b. Pendokumentasian secara menyeluruh terhadap arsitektur Gereja Katolik Kelahiran Santa Perawan Maria sebagai obyek kasus yaitu melalui gambar 2D, foto detail eksterior dan interior pada bangunan.

Pemilihan objek dengan menggunakan teknik purposive sampling yaitu teknik sampling yang objek ditentukan berdasarkan eksplorasi kekayaan informasi yang relevan sesuai dengan penelitian ini (Agustina Dewi et al., 2019). Obyek penelitian yang digunakan dalam penelitian ini adalah Gereja Katolik Kelahiran Santa Perawan Maria yang memiliki karakter langgam arsitektur kolonial yang memiliki fungsi sebagai ruang public dan masih difungsikan dan tidak banyak mengalami perubahan pada façade bangunan.

Teknik pengumpulan data dengan menggunakan obyek yang memiliki ruang di dalamnya masih berfungsi untuk aktivitas, maka dapat membantu mengidentifikasi karakter spasial. Karakter spasial tersebut seperti fungsi ruang,organisasi ruang, orientasi bangunan, hubungan ruang, sirkulasi ruang dapat membantu identifikasi karakter dari sebuah obyek arsitektur (Tanjungansari et al., 2016).

\subsection{Metode Analisa Data}

Analisa data dilakukan yaitu terhadap data yang didapatkan pada studi lapangan disesuaikan dengan kebutuhan data dan kemudian akan dideskripsikan secara kualitatif berdasarkan elemen arsitektural façade maupun interior bangunan dalam menjawab pertanyaan penelitian mengenai identifikasi karakter arsitektur. Data yang didapatkan kemudian dilakukan penentuan indikator untuk dapat mengidentifikasi karakter arsitektur Gereja Katolik Kelahiran Santa Perawan Maria. Data di lapangan dapat digunakan untuk menentukan dalam membentuk indikator mengidentifikasi karakter arsitektur Gereja Katolik Kelahiran Santa Perawan Maria. Indikator dapat mempermudah penelitian ini dalam memperlihatkan identifikasi karakter langgam dari obyek Gereja Katolik Kelahiran Santa Perawan Maria. Indikator yang digunakan dalam penelitian ini sebagai berikut:

Tabel 1. Parameter dan Indikator untuk Identifikasi Karakter

\begin{tabular}{clll}
\hline No. & \multicolumn{1}{c}{ Parameter } & Variabel & Indikator \\
\hline & & Jendela & $\begin{array}{l}\text { a. Bentuk Jendela } \\
\text { b. Figur Jendela }\end{array}$ \\
& & Pintu Masuk & Posisi \\
& $\begin{array}{l}\text { Elemen arsitektural eksterior } \\
\text { bangunan }\end{array}$ & Bentuk Atap & Bentuk Atap \\
& Dinding & $\begin{array}{l}\text { a. Material } \\
\text { b. Bentuk Plafon }\end{array}$ \\
\hline 2 & $\begin{array}{l}\text { Elemen Arsitektural Interior } \\
\text { Bangunan }\end{array}$ & Denah dasar & a. Fungsi Ruang \\
& & & b. Pola Ruang \\
\hline
\end{tabular}

(Sumber: Analisa Pribadi, 2021)

Analisa data tidak hanya pada parameter dan indikator saja tetapi juga menghitung nilai prosentase adopsi langgam arsitektur klasik pada tiap elemen-elemen arsitektural. Obyek dianalisa berdasarkan lima rupa yaitu pertembokan, pertiangan, perlindungan, perlubangan dan persolekan, dengan melihat ciri khas dari masing-masing pembentuk unsur karakter arsitektur klasik pada tiap elemen arsitektural, seperti jendela, plafon, pintu masuk utama, hiasan, pilar-pilar yang ada pada Gereja Katolik Kelahiran Santa Perawan Maria itu. Cara perhitungan prosentase adopsi langgam sebagai berikut:

Tabel 2. Perhitungan Nilai Prosentase

\begin{tabular}{lllll}
\hline No & $\begin{array}{c}\text { Pembagian } \\
\text { Rupa }\end{array}$ & \multicolumn{1}{c}{$\begin{array}{c}\text { Ciri Khas sesuai } \\
\text { literatur }\end{array}$} & $\begin{array}{c}\text { Pembentuk Karakter } \\
\text { (elemen-elemen } \\
\text { arsitektural) }\end{array}$ & Nilai Prosentase \\
\hline $\mathbf{1}$ & Perlindungan & $\begin{array}{l}\text { Tiap ciri khas dari } \\
\text { langgam arsitektur klasik }\end{array}$ & Bentuk Atap & $\begin{array}{l}\text { Jika bentuk atap memiliki } \\
\text { langgam arsitektur klasik } \\
\end{array}$ \\
& $\begin{array}{l}\text { yang sesuai dengan } \\
\text { literatur yang terlihat } \\
\text { pada obyek }\end{array}$ & $\begin{array}{l}\text { tertentu maka nilai = 1. } \\
\text { Sehingga, }\end{array}$ \\
\hline
\end{tabular}




\begin{tabular}{|c|c|c|c|}
\hline & & & $\frac{1}{5} \times 100 \%=40 \%$ \\
\hline 2 & Pertembokan & \multicolumn{2}{|l|}{ Plafon } \\
\hline & Perlubangan & \multirow[t]{4}{*}{$\begin{array}{l}\text { a. Jendela } \\
\text { b. Pintu masuk }\end{array}$} & $\begin{array}{l}\text { Jika pada bagian } \\
\text { perlubangan jendela dan } \\
\text { pintu masuk memiliki } \\
\text { langgam arsitektur klasik } \\
\text { yang sama maka nilai }=2 \text {. } \\
\text { Sehingga, }\end{array}$ \\
\hline & & & $\frac{2}{5} \times \quad 100 \%=40 \%$ \\
\hline & & & $\begin{array}{l}\text { Tetapi jika langgam yang } \\
\text { dimiliki antara pintu masuk } \\
\text { dan jendela berbeda maka, }\end{array}$ \\
\hline & & & $\frac{1}{5} \times 100 \%=40 \%$ \\
\hline & Pertiangan & $\begin{array}{l}\text { a. Tiang structural } \\
\text { b. Tiang non struktural }\end{array}$ & $\begin{array}{l}\text { Jika pada bagian } \\
\text { pertiangan memiliki } \\
\text { langgam arsitektur klasik } \\
\text { yang tiang nonstruktural } \\
\text { dan structural di beberapa } \\
\text { bagian, maka nilai tiap } \\
\text { bagian }=1 \text {. Misal, tiang } \\
\text { nonstruktural langgam } \\
\text { Gothic di pintu masuk, di } \\
\text { bagian tengah bangunan } \\
\text { maka nilai }=2 \text {. Jadi, }\end{array}$ \\
\hline & & & $\frac{2}{5} \times 100 \%=40 \%$ \\
\hline & Persolekan & Bentuk Patung/hiasan & $\begin{array}{l}\text { Jika pada bagian } \\
\text { persolekan memiliki } \\
\text { langgam arsitektur klasik } \\
\text { yang ada beberapa bagian, } \\
\text { maka nilai tiap bagian }=1 \text {. } \\
\text { Misal bagian persolekan } \\
\text { langgam Gothic pada } \\
\text { patung dan rose window } \\
\text { maka nilai }=2 \text {. Jadi, }\end{array}$ \\
\hline & & & $\frac{2}{5} \times 100 \%=40 \%$ \\
\hline
\end{tabular}

(Sumber: Analisa Pribadi, 2021)

Pembacaan hasil nilai prosentase yaitu berdasarkan masing-masing elemen arsitektural pada gereja Katolik Kelahiran Santa Perawan Maria ini. Perhitungan dan pembacaan analisa sebagai berikut:

Misal, jika pada bagian perlubangan antara jendela dan pintu masuk memiliki langgam arsitektur klasik yang sama maka nilai $=2$. Sehingga, 


$$
\frac{2}{5} \times 100 \%=40 \%
$$

Tetapi jika langgam yang dimiliki antara pintu masuk dan jendela berbeda maka perhitungan prosentase:

$$
\frac{1}{5} \quad \times 100 \%=40 \%
$$

\section{Hasil dan Pembahasan}

Pada bagian façade bangunan Gereja Kelahiran Santa Perawan Maria tampak bata merah yang terekspos pada permukaan bagian luar dinding. Dari gambar site terlihat bentuk denah yang memiliki proporsi atau disebut golden section, sehingga gereja ini memiliki bentuk yang simetris. Bentuk tersebut merupakan ciri dari gaya arsitektur Yunani. Proporsi dalam desain arsitektur merupakan prinsip kesetimbangan visual yang bertujuan untuk membentuk keteraturan rasio di antara unsur pembentuknya, salah satu proporsi disebut golden section (Sani, 2017). Di atas pintu masuk utama terdapat jendela berbentuk lingkungan dengan elemen-elemen radial dengan kaca patri, yang merupakan ciri khas dari arsitektur Gotik. Elemen kaca berbentuk radial itu disebut rose window. Jendela ini memiliki berfungsi untuk memasukkan cahaya matahari dari luar bangunan dan estetika, secara filosofi rose window itu disimbolkan sebagai cahaya yang masuk dan menerangi isi hati umat gereja. Pada façade bangunan terdapat dua menara di mana ujung atasnya dihiasi oleh menara runcing penuh dengan ornamen besi. Masing-masing menara memiliki ketinggian 15 meter, ditambahkan salib setinggi 3,75 meter. Keberadaan menara pada gereja itu difungsikan sebagai isyarat adanya peribadatan di dalam gereja, sedangkan pada jaman sekarang biasanya di beri lonceng tepat di atas menara tersebut. Bangunan Gereja katolik Kelahiran Santa Perawan Maria ini memiliki langgam Gotik dengan yang mengandalkan sistem triforium untuk menyangga bangunan dan juga memiliki sistem flying buttress. Bentuk runcing tersebut sangat sering ditemui dalam bangunan ini, contohnya seperti pada bagian atap, jendela, Bentuk demikian merupakan salah satu ciri khas yang dimiliki oleh arsitektur Gothic. Sehingga, secara tampak pada bagian façade bangunan sangat terasa kesan dari arsitektur Gothic.

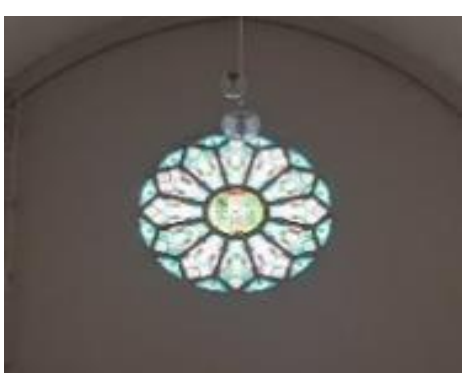

Gambar 1. Rose window pada Gereja GKSPM

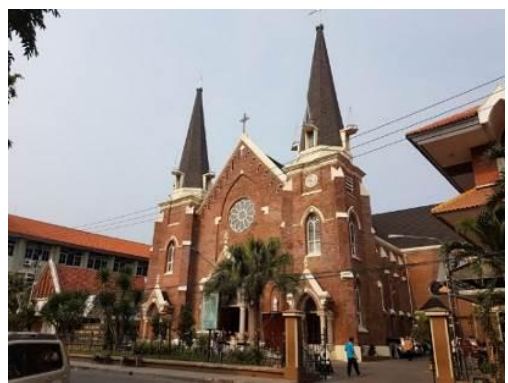

Gambar 2. Bagian façade bangunan

(Sumber: Dokumentasi Pribadi, 2020)

Menurut Yulianto (2003) arsitektur Gotik memiliki ciri-ciri yaitu bangunan memiliki ketinggian langit-langit yang jauh melebihi skala manusia, bangunan memiliki bentuk busur yang meruncing, bentuk pengembangan bentuk rib vaults bentuk kubah yang menyerupai rusuk, kolom tidak hanya bersifat structural tetapi juga nonstructural, dan terdapat rose windows (Yunani, 2018). Ciri tersebut dapat terlihat pada wujud fisik Gereja Katolik Kelahiran Santa Perawan Maria ini yaitu pada bentuk plafon yang tinggi melebihi skala manusia dan berbentuk rib vault. Jika melihat pada bagian interiornya, melihat pada plafon bangunan gereja ini, memiliki barrel vault yang berbentuk melengkung. Bentuk barrel vault pada plafon Gereja terlihat memiliki kemiripan dengan barrel vault pada langgam arsitektur Romawi, yaitu keduanya memiliki bentuk yang melengkung. Tetapi kemiripan sama-sama melengkung, tetap terdapat perbedaan yaitu pada arsitektur Gothic bagian ujung atas tampak sedikit meruncing dan barrel vault menerus dari kolom ke bagian langit-langit bangunan. Wujud fisik yang demikian yang terdapat pada plafon gereja Kelahiran Santa Perawan Maria, sehingga dapat terlihat jelas penerapan langgam arsitektur Gothic. 

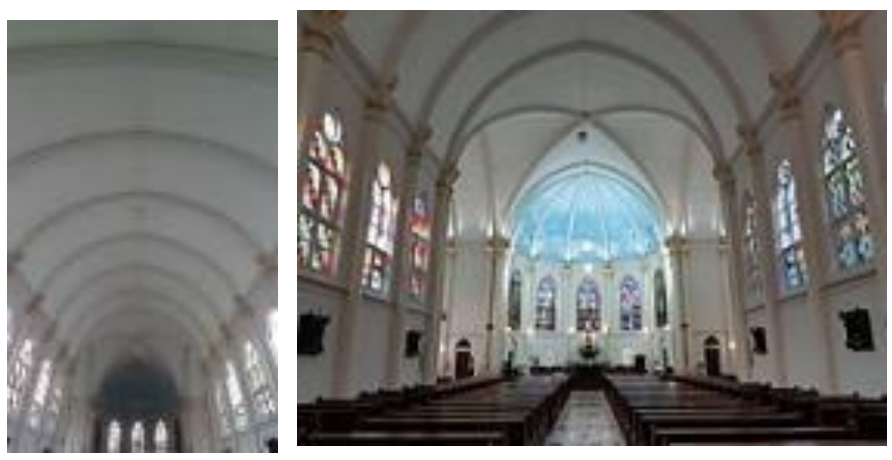

Gambar 3. Barrel vault pada gereja GKSPM

(Sumber: Dokumentasi Pribadi, 2020)

Pada bagian pertiangan bangunan, terdapat kolom yang terdiri dari beberapa kolom-kolom kecil yang dijadikan satu dan menerus ke atas. Hal tersebut dimaksudkan agar bangunan tampak menjulang tinggi ke atas, dengan filosofi semakin bangunan itu tinggi akan semakin dekat dengan sang pencipta. Selain itu, fungsi dari kolom yang berukuran kecil-kecil itu memberi sense of place atau kesan bangunan yang tampak meninggi. Ada juga kolom-kolom kecil yang fungsinya hanya sebagai hiasan atau merupakan kolom non-struktural, sehingga hanya menjadi ornament atau hiasan pada bangunan. Bisa juga ada satu kolom besar yang diselubungi kolom-kolom kecil, sehingga kolom besar tersebut merupakan kolom struktural dan kolom kecil itu sebagai kolom non-strukturalnya. Kolom-kolom yang berukuran kecil ini merupakan ciri yang dimiliki oleh gaya arsitektur gotik.

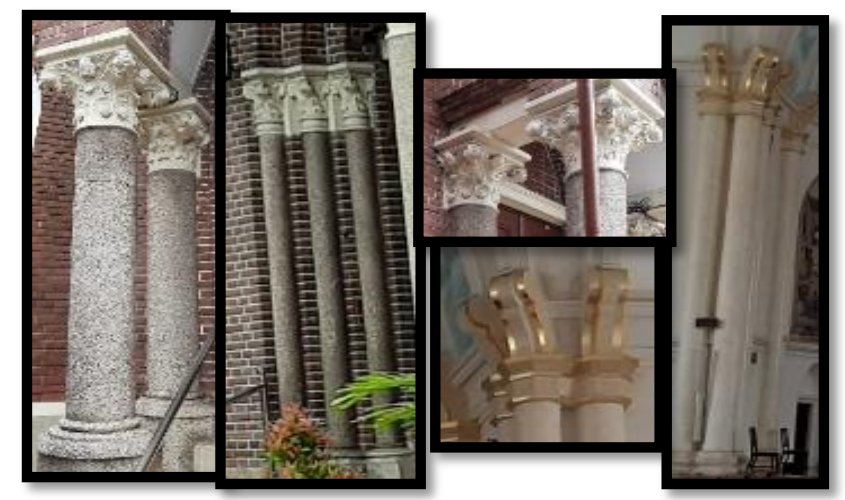

Gambar 4. Kolom di interior dan eksterior gereja GKSPM (Sumber: Dokumentasi Pribadi, 2020)

Dari gambar 4. terlihat bahwa pada bagian depan bangunan tampak bahwa kolom yang digunakan merupakan kolom composite. Dikatakan sebagai kolom composite karena pada bagian atas kolom terlihat adanya perpaduan antara bentuk tanduk domba dengan ukiran daun acanthus. Kolom jenis ini menciptakan kesan yang indah dan luwes serta terlihat anggun, sehingga membuat bangunan terlihat menarik dan berkarakteristik. Kolom jenis ini ditemukan ada gaya arsitektur Romawi.

Memiliki lebih banyak ornamen. Gaya arsitektur gotik tampak lebih rumit, sebab terdapat banyak ornamen pada bagian dalam ruangan maupun eksterior bangunan pada gereja ini sendiri, pada bagian luar maupun dalam bangunan dilengkapi banyak patung-patung santa dan santo yang menghiasi bangunan ini. Selain itu, terdapat juga lukisan dari ukir-ukiran kayu yang menempel pada dinding bagian dalam ruangan. Ornamen-ornamen dengan bentuk 3D ini merupakan kekhasan dari gaya arsitektur barok. Pada masa early Gothic sculpture memiliki bentuk yang tidak sesuai dengan proporsi manusia terdapat gargoyle. Tetapi mengalami perkembangan high Gothic hingga NeoGothic yaitu bentuk sculpture sudah memiliki ukuran lebih sederhana dan tidak terdapat gargoyle. Seperti yang terlihat pada sculpture yang ada pada gereja Kelahiran Santa Perawan Maria. 

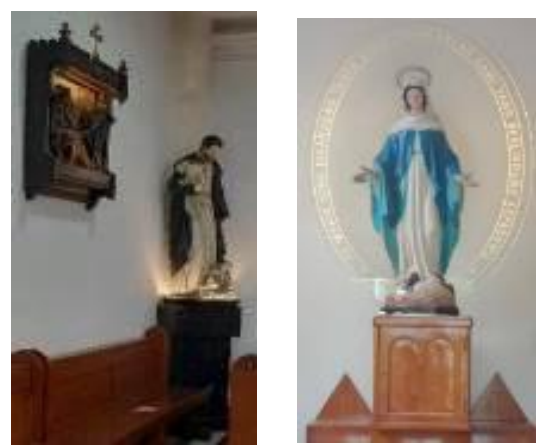

Gambar 5. Patung

(Sumber: Dokumentasi Pribadi, 2020)

Pada bagian perlubangan bangunan ini memiliki pola dalam perancangannya. Terdapat ritme pengulangan dan keteraturan bentuk pada berbagai bagian dalam bangunan. Salah satunya pada bentuk jendela maupun ornamenornamen lainnya, seperti yang terlihat pada gambar. Adanya keselarasan bentuk dan ritme pengulangan tersebut diadaptasi dari gaya arsitektur Renaissance. Sebab, bila dalam arsitektur renaissance keindahan pada sebuah bangunan itu akan Nampak apabila terdapat keteraturan pola di dalamnya, baik dalam segi keseimbangan maupun bentuk yang menciptakan suatu pola. Dalam segi keseimbangan dapat terlihat dari denah yang memiliki proporsi antara masing-masing bagian bila dibagi menjadi dua bagian. Sedangkan, bentuk yang menciptakan suatu pola terlihat khususnya pada bagian interior bangunan, seperti yang terlihat pada foto di bawah ini (Gambar 6).
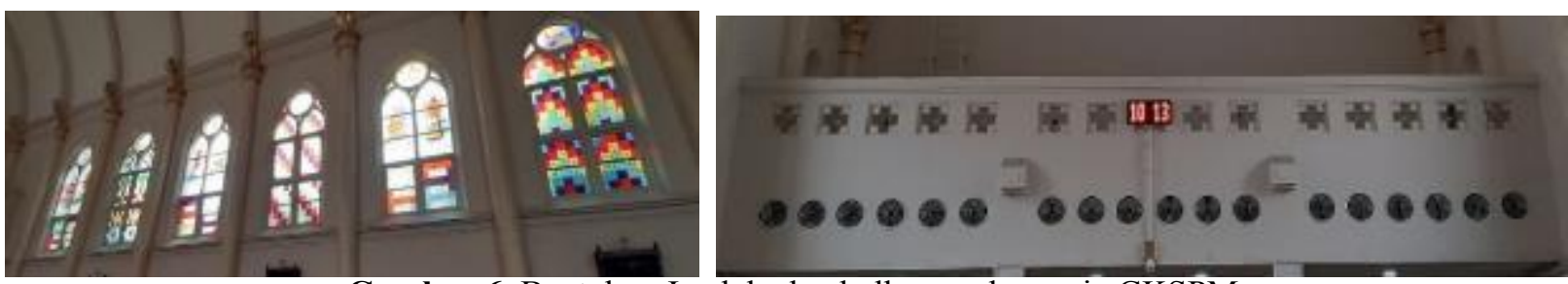

Gambar 6. Bentukan Jendela dan balkon pada gereja GKSPM

(Sumber: Dokumentasi Pribadi, 2020)

Pada interior bangunan tidak terlalu meriah, akan tetapi tetap ada beberapa bagian yang dihias. Seperti yang terlihat gambar 7, bagian atas khususnya pada langit-langit tempat altarnya diberi lukisan bergambar langit biru dengan awan-awan putih. Warna-warna yang digunakan cenderung warna yang cerah. Arsitektur Rococo pada bagian interior penuh dengan dekorasi atau ornamen, karena pada saat itu banyak bermunculan pelukis. Sehingga bangunan itu dianggap sebagai sebuah kanvas, mereka menuangkan idenya pada lukisan bangunan. Selain langitlangit, terdapat juga dua buah lukisan pada sisi kanan dan kiri jendela yang memiliki bentuk serta ukuran yang sama dengan jendela. Pada bagian atas kolom diberi sentuhan warna emas yang umumnya banyak ditemukan pada gaya arsitektur Baroque. Sedangkan, pada tiap jendela selalu diberi kaca patri bukan kaca biasa. Kaca jendela pada arsitektur yang mengadopsi langgam Gotik tidak hanya sekedar memberikan unsur estetika, tetapi sebagai simbol dalam menciptakan suasana sakral dalam interior. Kaca patri ini memiliki banyak gambar, entah itu hanya berupa simbol atau berbagai macam warna, dengan gambaran yang paling rumit berada pada tiga jendela tempat altar.

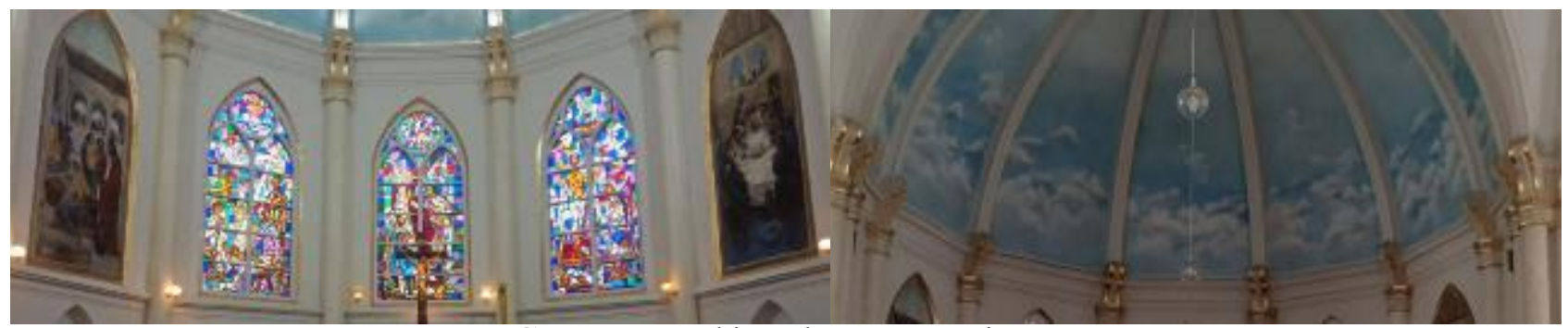

Gambar 7. Lukisan dan Kaca Patri

(Sumber: Dokumentasi Pribadi, 2020) 
Bentuk bangunan yang cenderung meruncing tidak hanya pada bagian luarnya tetapi juga pada bagian dalam ruangan. Begitu juga pada bentuk arch-nya juga dibuat meruncing. Alasan yang mendasari munculnya bentuk meruncing tersebut karena adanya kebosanan, sehingga pada arsitektur gotik diciptakan bentuk yang berbeda dari gaya arsitektur sebelumnya yang kebanyakan memiliki bentuk melengkung, seperti pada arsitektur romawi hingga arsitektur bizantium. Pada bangunan ini juga digunakan banyak bentuk yang meruncing baik pada jendela maupun pintunya.
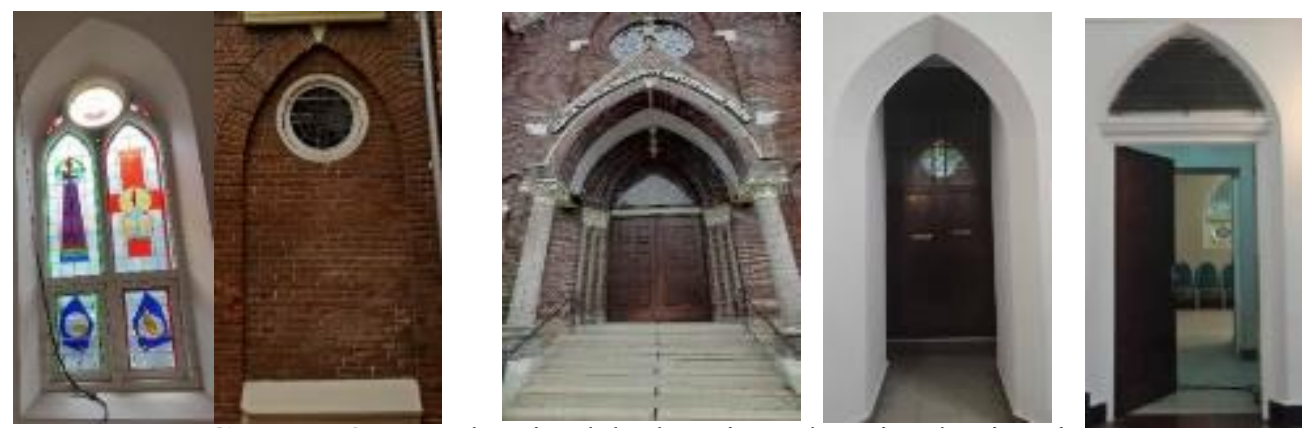

Gambar 8. Bentukan jendela dan pintu eksterior dan interior

(Sumber: Dokumentasi Pribadi, 2020)

Tabel 3. Analisa Identifikasi Lima Rupa pada Gereja GKSPM

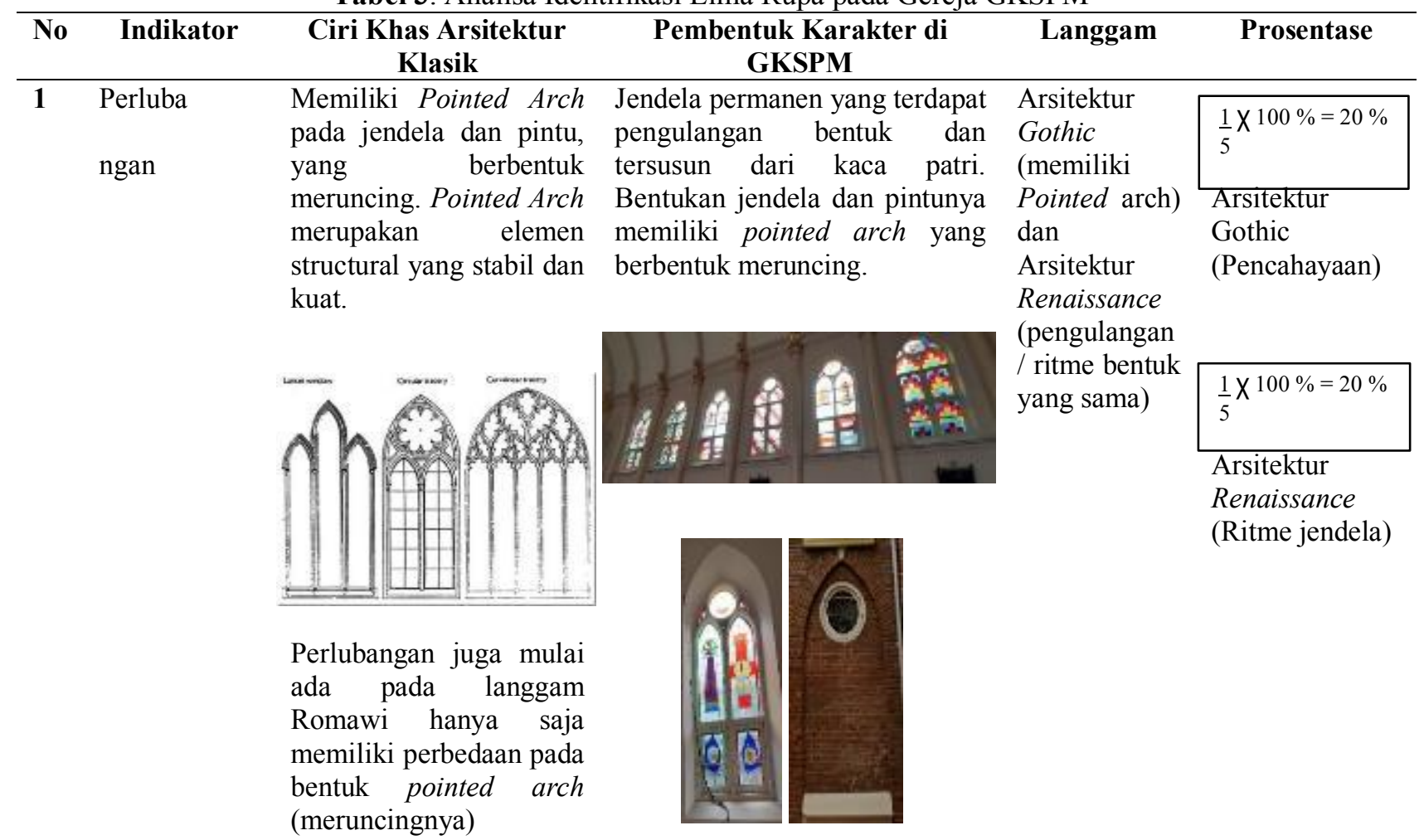
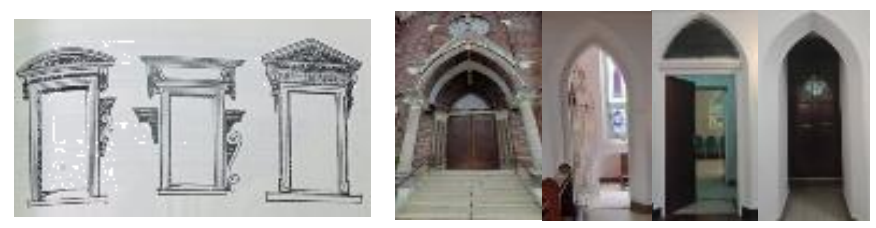

(Tzonis, 1992) 


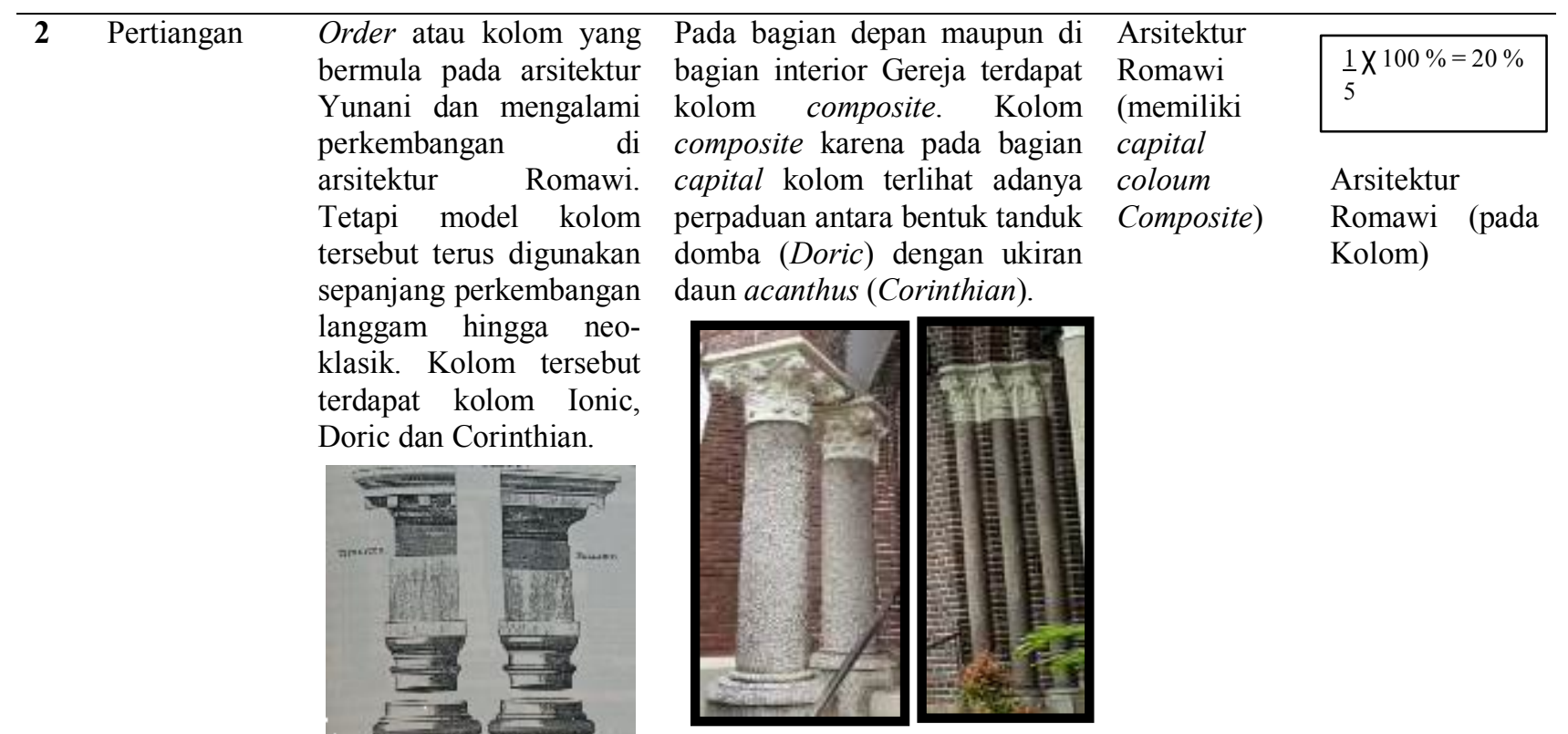

Kolom jenis ini menciptakan kesan yang indah dan luwes serta terlihat anggun, sehingga membuat bangunan terlihat menarik dan berkarakteristik.

Capital and Base Ionic Column

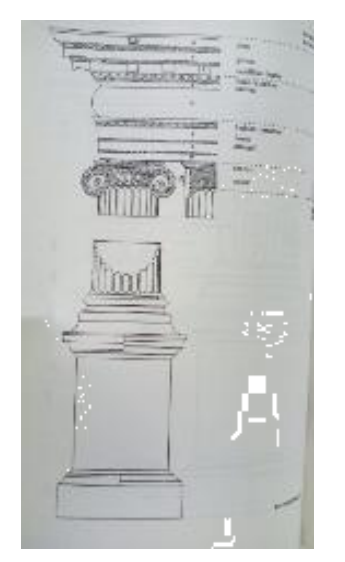

$$
\text { Kolom Doric }
$$

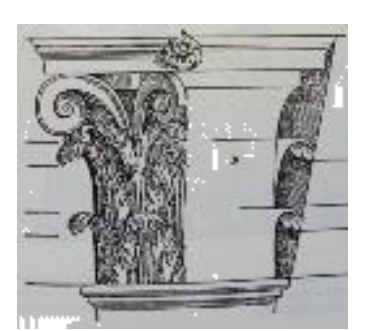

Kolom Corinthian

(Tzonis, 1992)

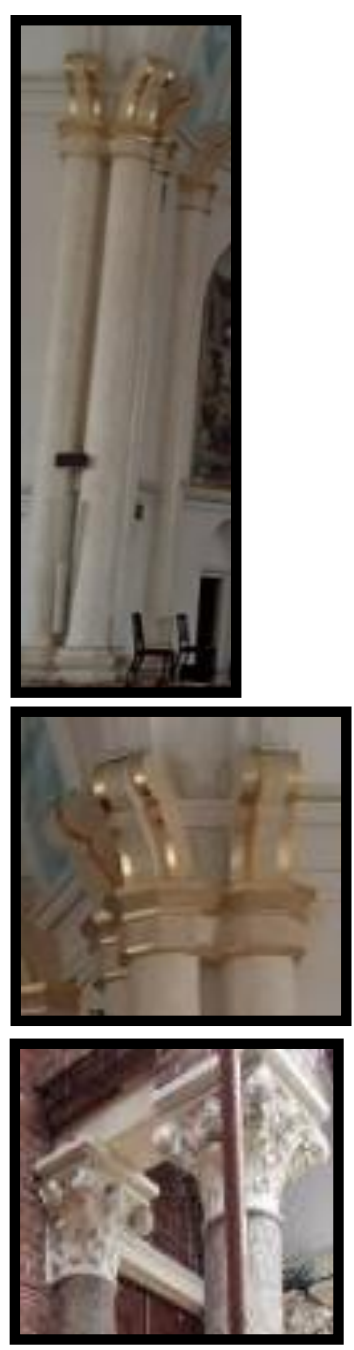




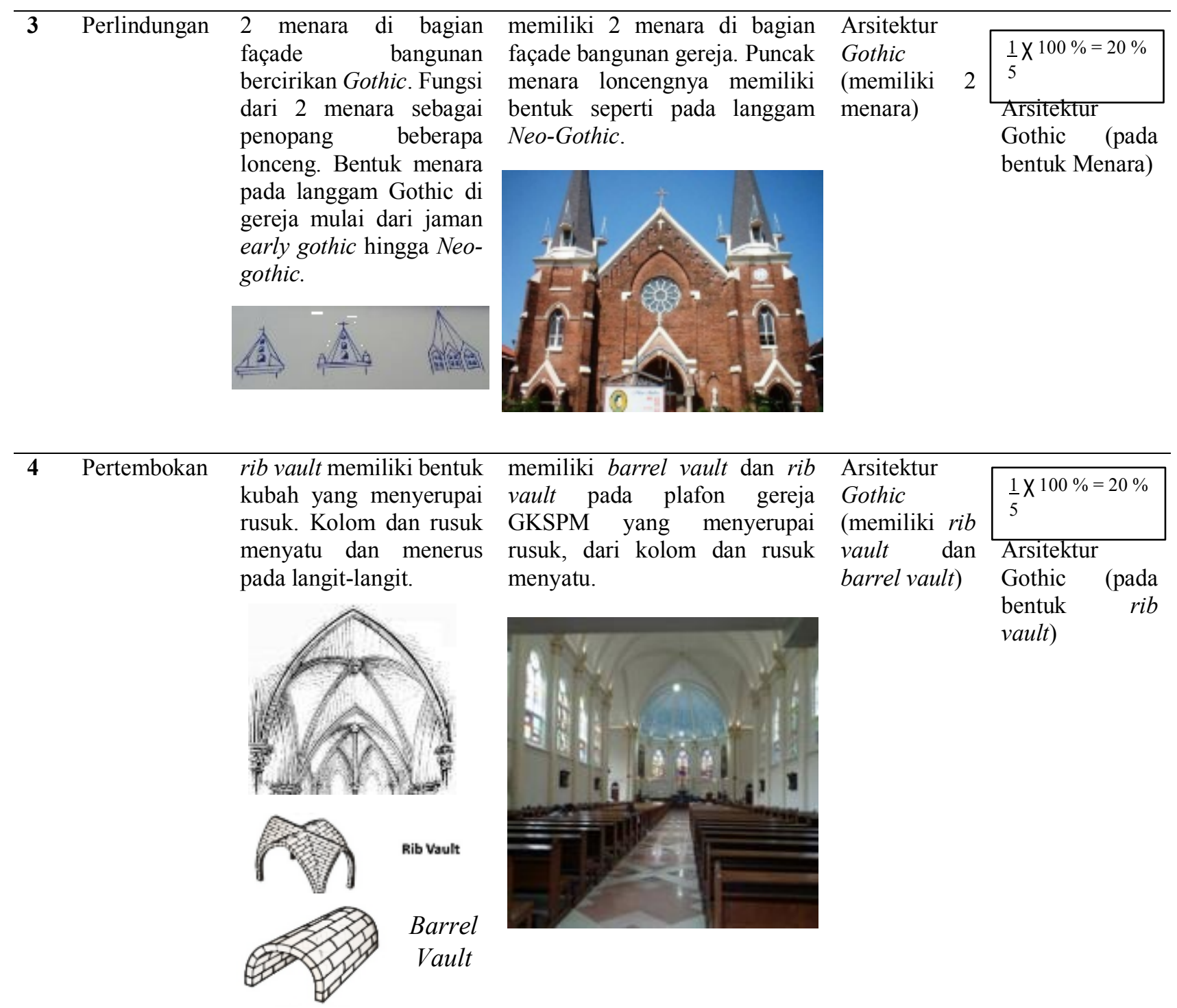

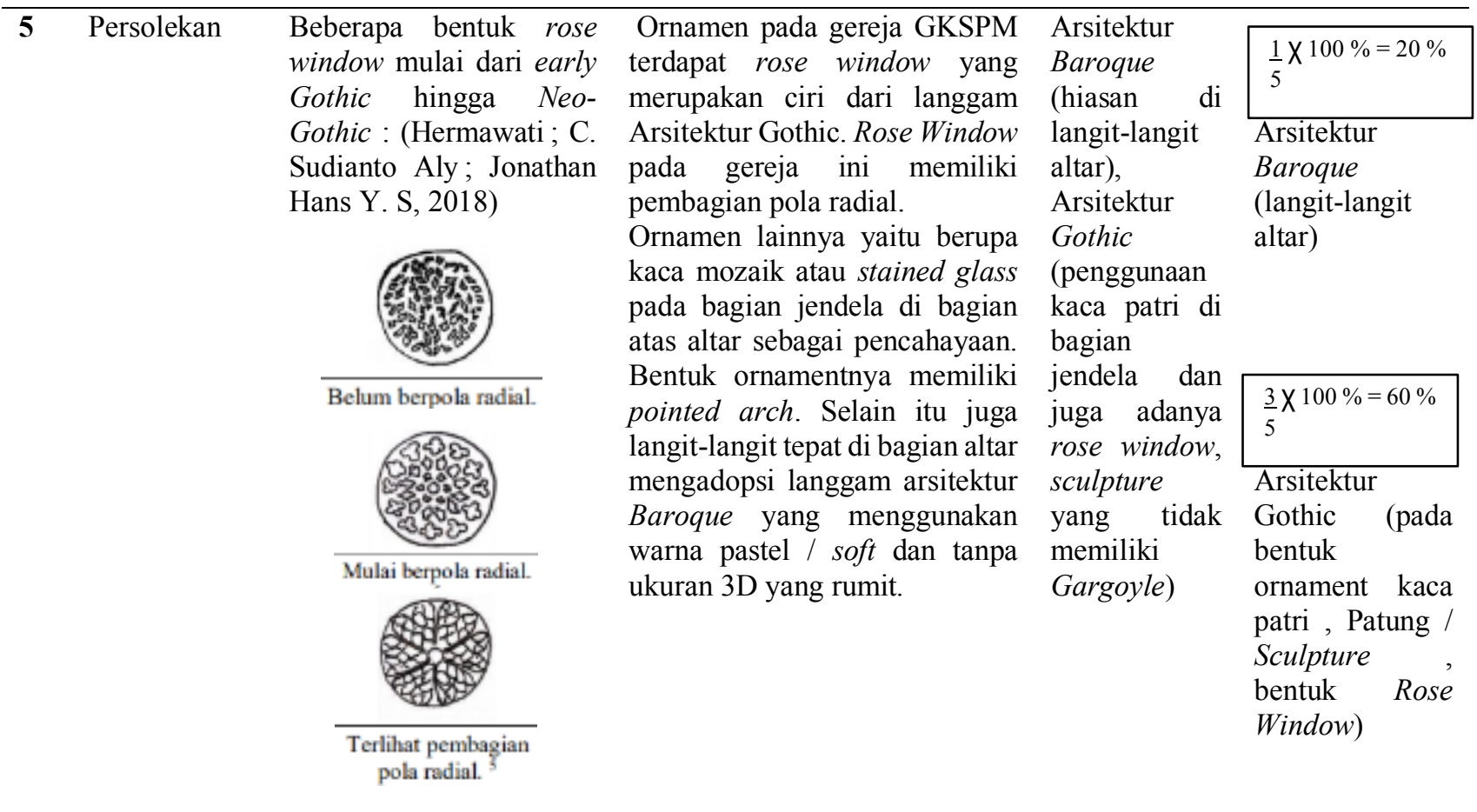




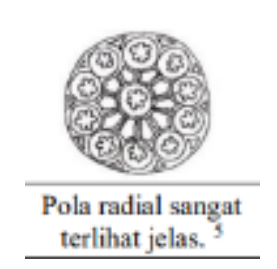

Selain Rose Window persolekan atau ornament yang mengidentikkan suatu langgam yaitu bentuk Stained Glass yang merupakan kaca mozaik / patri yang digunakan untuk akses sinar matahari ke dalam ruangan. Selain itu sebagai fungsi estetika. Gambar yang ada di kaca patri memiliki cerita tentang Yesus.

\section{(1) 新}

(Hermawati ; C. Sudianto Aly ; Jonathan Hans Y. S, 2018)

Persolekan juga dapat terlihat dari adanya sculpture yang ada di dalam Gereja, seperti patung Yesus, Bunda Maria, dan lain-lain. Sculpture mengalami perkembangan mulai dari early Gothic hingga NeoGothic:

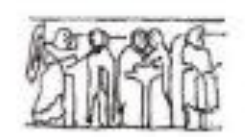

Sculpture early

Gothic

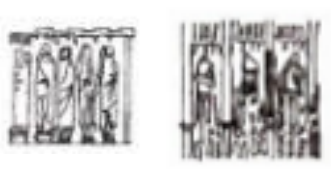

Sculpture High Gothic

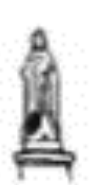

Sculpture Neo-Gothic
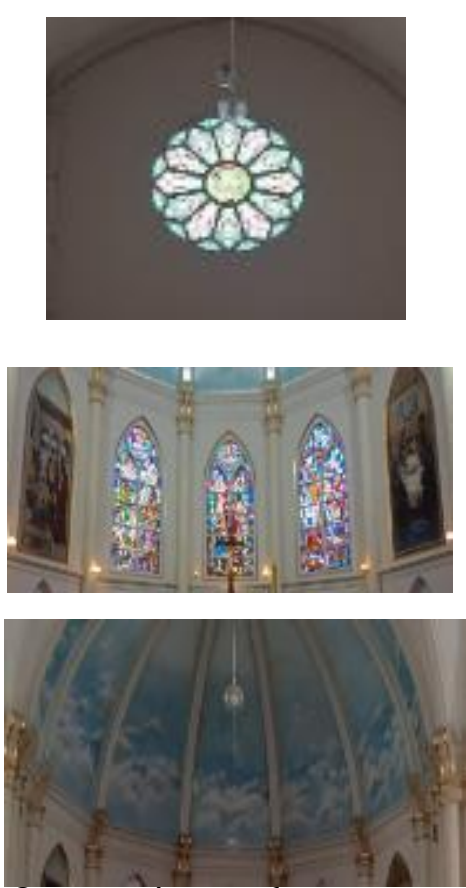

Ornamen juga terdapat patungpatung yang memiliki bentuk sculpture yang proporsinya tidak terlalu besar dan tidak memiliki Gargoyle.
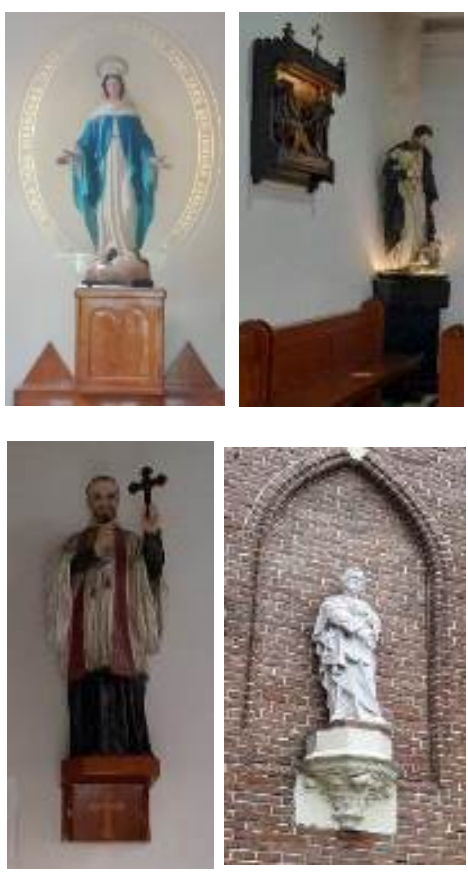

Sculpture Neo-Gothic

(Sumber: Analisis Pribadi, 2021) 
Tabel 4. Parameter dan Indikator untuk Identifikasi Karakter

\begin{tabular}{|c|c|c|c|c|}
\hline No. & Parameter & Variabel & Indikator & Keterangan \\
\hline 1 & $\begin{array}{l}\text { Elemen arsitektural eksterior } \\
\text { bangunan }\end{array}$ & Jendela & $\begin{array}{l}\text { a. Bentuk Jendela } \\
\text { b. Figur Jendela }\end{array}$ & $\begin{array}{l}\text { Bentuk Jendela dan figur jendela } \\
\text { pada gereja ini mengadopsi } \\
\text { langgam Gothic sebab memiliki } \\
\text { Pointed arch yang berulang dan } \\
\text { berfungsi sebagai jendela maupun } \\
\text { hanya sebagai memasukkan } \\
\text { cahaya ke dalam interior. }\end{array}$ \\
\hline
\end{tabular}
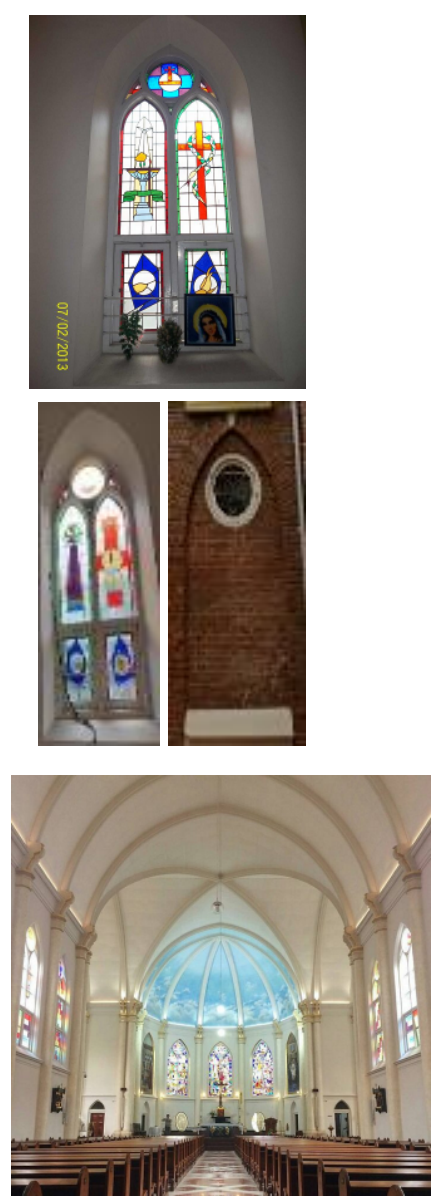

\begin{tabular}{lll}
\hline Pintu Masuk & Posisi & Bentuk pintu Gotic yang sangat \\
& & luas, dan memiliki bentuk \\
& melengkung majemuk, runcing di \\
& atas (pointed arch) dan kolom- \\
& kolom kecil silindris. \\
& & \\
& &
\end{tabular}




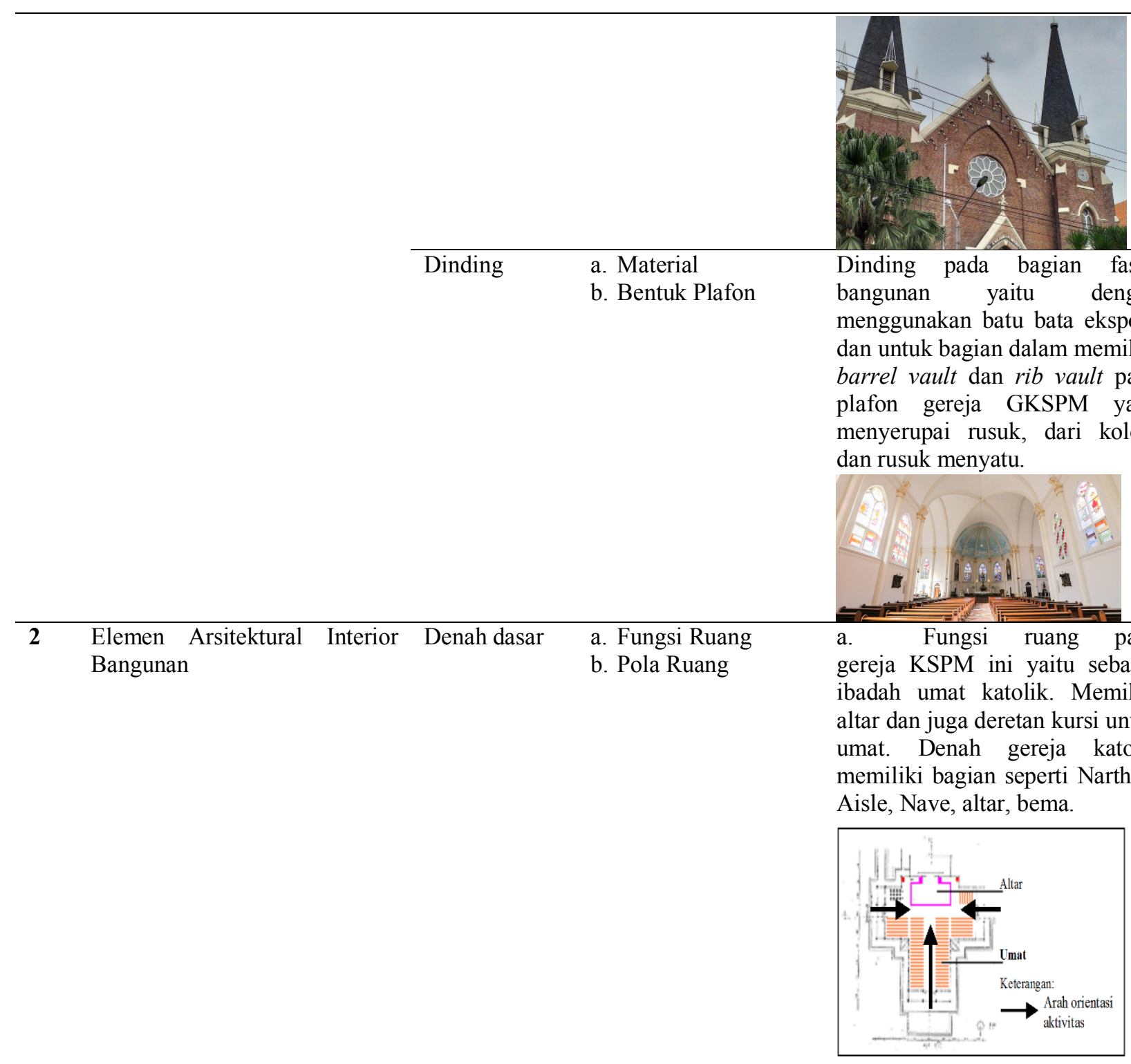

(Sriti Mayang Sari \& Jessyca Setyaprana, 2007)

b. Untuk bentuk pola ruang lebih pada bentuk denah salib mendapat pengaruh liturgi gereja katolik Roma.

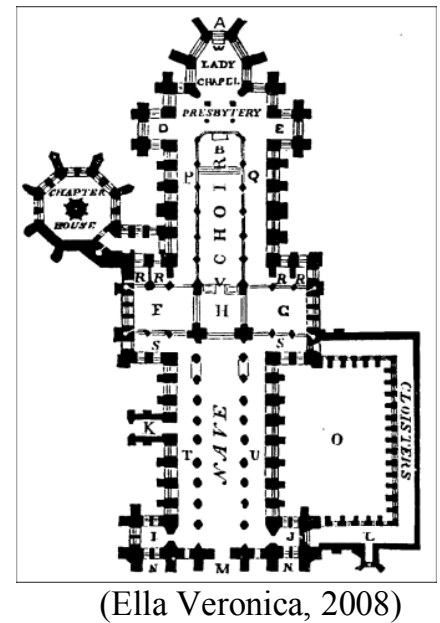




\section{Kesimpulan}

Facade bangunan merupakan elemen arsitektur yang sangat dominan dalam memperlihatkan karakter arsitektur, dan dapat teridentifikasi bahwa bangunan tersebut mengadopsi salah satu langgam arsitektur. Berdasarkan identifikasi yang telah dilakukan terhadap gereja Kelahiran Santa Perawan Maria dapat disimpulkan bahwa karakter langgam dari Gereja ini memiliki persentase penilaian $100 \%$ mengadopsi langgam arsitektur Gothic. Dari tabel. 1 identifikasi pembentuk karakter gereja GKSPM terlihat bahwa ada beberapa langgam yang diadopsi pada gereja tersebut yaitu ditemukan langgam arsitektur Romawi, langgam arsitektur Renaissance, langgam arsitektur Baroque dan langgam arsitektur Gothic. Berdasarkan perhitungan prosentase yang dilakukan pada kelima rupa yaitu pertiangan, perlubangan, perlindungan, pertembokan, dan persolekan, maka ditemukan bahwa langgam arsitektur Renaissance memiliki persentase $20 \%$ yaitu terlihat pada pengulangan bentuk / ritme pada pencahayaan yang berbentuk pointed arch. Langgam arsitektur Romawi memiliki $20 \%$ teradopsi pada bentuk capital kolom Composite yang ada pada eksterior dan interior gereja. Langgam arsitektur Baroque juga memiliki persentase $20 \%$ yang terdapat pada motif serta ornamen di langit-langit di atas altar. Sedangkan prosentase yang paling tinggi yaitu langgam arsitektur Gothic yaitu sebanyak $60 \%$ yaitu terdapat pada bentuk ujung menara lonceng, bentuk patung / sculpture, bentuk rose window yang sangat identik dengan langgam arsitektur Gothic di masanya. Walaupun gereja ini memiliki pembentuk karakter dengan mengadopsi langgam arsitektur yang bervariasi, tetapi langgam arsitektur tersebut membawa ciri khas yang memberikan keunikan tersendiri pada Gereja Katolik Kelahiran Santa Perawan Maria.

\section{Ucapan Terima Kasih}

Ucapan terima kasih kepada semua pihak Gereja Kelahiran Santa Perawan Maria dan juga dosen pembimbing yang telah memberikan dukungan, ijin dan bantuan dalam terlaksananya penelitian ini terkait survey lapangan, sehingga penelitian ini dapat terselesaikan dengan baik. Semoga hasil dari penelitian ini dapat berguna dan memberi manfaat bagi pembaca dan peneliti selanjutnya.

\section{Daftar Pustaka}

Agusintadewi, N. K., Prajnawrdhi, T. A., \& Satria, M. W. (2019). Karakter Arsitektural Bangunan Kolonial sebagai Warisan Budaya Kota Singaraja. Jurnal Lingkungan Binaan Indonesia, 8(1). https://doi.org/10.32315/jlbi.8.1.16

Ella Veronica. (2008). PENGARUH LITURGI GEREJA KATOLIK ROMA PADA INTERIOR GEREJA KELAHIRAN SANTA PERAWAN MARIA. Dimensi Interior.

Hermawati ; C. Sudianto Aly ; Jonathan Hans Y. S, S. (2018). THE APPLICATION OF GOTHIC ARCHITECTURE ON SANTO LAURENSIUS CHIRCH ALAM SUTRA, SERPONG. Riset Arsitektur (RISA). https://doi.org/10.26593/risa.v2i04.3047.358-371

Kumurur, V. A. (2015). Pengaruh Gaya Arsitektur Kolonial Belanda pada Bangunan Bersejarah di Kawasan Manado Kota Lama. Prosiding Temu Ilmiah IPLBI, May, 167-172.

Laurens, J. M. (2013). Memahami Arsitektur Lokal dari Proses Inkulturasi pada Arsitektur Gereja Katolik di Indonesia. Seminar Nasional Reinterpretasi Identitas Arsitektur Nusantara.

Putra, B. N., Antariksa, \& Ridjal, A. M. (2017). Pelestarian Bangunan Kolonial Museum Fatahillah di Kawasan Kota Tua Jakarta. Jurnal Arsitektur.

Sahmura, Y., \& Wahyuningrum, S. H. (2018). IDENTIFIKASI LANGGAM DAN PERIODISASI ARSITEKTUR KOLONIAL NUSANTARA PADA BANGUNAN CAGAR BUDAYA. MODUL. https://doi.org/10.14710/mdl.18.2.2018.60-69

Sani, A. A. (2017). STUDI EKSPLORASI PROPORSI GOLDEN SECTION PADA TUBUH MANUSIA-INDONESIA. Jurnal Arsitektur ARCADE. https://doi.org/10.31848/arcade.v1i2.21

Saputra, A., \& Prabowo, S. (2014). The birth of the Blessed Virgin Mary Church located at Jl . Kepanjen Surabaya is one of the oldest standing church in Indonesia. This church is one of the historic buildings in use as a cultural heritage by the government of Surabaya . This church has a. Jurnal Pendidikan Seni Rupa, 2, 62-69.

Sriti Mayang Sari, \& Jessyca Setyaprana. (2007). INKULTURASI BUDAYA JAWA DALAM INTERIOR GEREJA KATOLIK REDEMPTOR MUNDI DI SURABAYA. Dimensi Interior.

Sukawi, S. (2004). ARSITEKTUR BIZANTIUM PADA DOME OF THE ROCK. Jurnal Jurusan Arsitektur.

Tamimi, N., Fatimah, I. S., \& Hadi, A. A. (2020). Tipologi Arsitektur Kolonial di Indonesia. Jurnal Arsitektur, Bangunan Dan Lingkungan.

Tanjungansari, C. A., Antariksa, A., \& Suryasari, N. (2016). Karakter Spasial Bangunan Gereja Blenduk (GPIB IMMANUEL) Semarang. Jurnal Mahasiswa Jurusan Arsitektur.

Wihardyanto, D., \& Sudaryono, S. (2020). ARSITEKTUR KOLONIAL BELANDA DI INDONESIA DALAM KONTEKS SEJARAH FILSAFAT DAN FILSAFAT ILMU. LANGKAU BETANG: JURNAL ARSITEKTUR. https://doi.org/10.26418/lantang.v7i1.35500

Yunani, A. (2018). Gereja Hati Yesus Yang maha Kudus - Katedral (sejarah Gereja Katolik di Sulawesi Selatan dan Tenggara). Jurnal Lektur Keagamaan. https://doi.org/10.31291/jlk.v15i1.518 